\title{
Theodor Fontane's Representation of Monuments in the Wanderungen durch die Mark Brandenburg
}

Kathrin Maurer ${ }^{1}$

\begin{abstract}
Theodor Fontane was a passionate visitor of historical monuments, and his text Wanderungen durch die Mark Brandenburg entail many references to sculptures, obelisks, churches, and museums. Fontane's description of monuments represents a specific view on history, which undermines a teleological perspective on the past. The article shows that Fontane's monuments embody eschatological, allegorical, and arabesque interpretations of the past, which in turn poetizes and de-historizes history.
\end{abstract}

Keywords: Fontane - representation of history - monuments - multiperspectivism

Zusammenfassung: Theodor Fontane war ein passionierter Besucher und Kenner historischer Denkmäler. Auch seine Texte weisen seine Begeisterung für das Historische auf, wie sein Werk Wanderungen durch die Mark Brandenburg mit seinen enthalten zahlreiche Referenzen auf Skulpturen, Obelisken, Kirchen und Museen besonders gut demonstriert. In diesem Artikel soll gezeigt werden, dass Fontanes Beschreibungen der dortigen Monumente eine spezifische Sicht auf historische Erinnerungsstätten aufweisen, die eine teleologische und nationale Sichtweise auf die Geschichte zum Teil unterwandern. Fontanes Denkmäler repräsentieren vielmehr einen mehrdimensionalen Geschichtsperspektivismus, in dem eschatologische, allegorische und arabeske Geschichtsmodelle gegeneinander konkurrieren.

Stichworte: Fontane - Geschichtsrepräsentation -Monumente - Multiperspektivismus

\section{Introduction}

"Von Kindesbeinen an hab ich eine ausgeprägte Vorliebe für die Historie gehabt. Ich darf sagen, dass diese Neigung mich geradezu beherrschte und meinen Gedanken wie meinen Arbeiten eine einseitige Richtung gab“ (FONTANE 1968: 146). These words by the German author Theodor Fontane (1819-1898) shed light on his curiosity towards matters of the past; an interest that shaped his numerous historical novels, his

\footnotetext{
${ }^{1}$ Associate Professor, German Studies, University of Southern Denmark. Email: kamau @litcul.sdu.dk
} 
autobiographical texts, and his essays on art history. This article focuses on Fontane's life-long infatuation for monuments in work. Many of his literary writings evince traces of his passion and contain descriptions of gravestones, sculptures, and churches, such as the statue of the temple knight in Schach von Wuthenow or the Chinese cemetery in Effi Briest, to name only a few examples. What kind of understanding of the past do Fontane's literary representations of the monuments suggest? In which ways do the monuments process memory? On the one hand, research interprets Fontane's representations of monuments as a political affirmation of the monument-boom in late nineteenth-century Germany (Comp. WÜSTEN 1970 and TONTSCH 1979). This was the trend to maintain, to build and to popularize national monuments supporting the political agendas of the Prussian regime. On the other hand, recent approaches describe it as a type of visual counter culture to precisely this official monument-mania. In these approaches the memorials, even though there are part of the official practices of remembering, embody a form of (vanishing) collective memory often characterized by Pierre Nora's notion of mémoire (THIELKING 2000 and GRAECENITZ 1993). My analysis aims to go beyond these viewpoints in showing that Fontane's representations of monuments neither politically affirm nor subvert the official memory practices of the Bismarck era. Focusing on Fontane's Wanderungen durch die Mark Brandenburg (1862-1882), a work that teems with descriptions of gravestones, statues, sculptures and other types of memorials, I demonstrate that its poetic representations of monuments experiment with diverse medial, cultural and religious traditions. Fontane's text cites allegorical, eschatological, dynastic, and national approaches towards the past without fixating one model over the other. They neither construct a point of origin, from where the past could be interpreted into a meaningful teleological narrative (histoire) nor do they produce moments of mémoire. Rather by de-centering these distinct models, they reflect about the conditions of the possibility of historical representation within the literary medium.

\section{Fontane: The Monument Hunter}

Fontane was a passionate visitor of monuments. He was member of numerous monument clubs, friends with one of Prussia's leading conservators, Ferdinand von 
Quast, as well as with the famous art historian Franz Kugler, whom he both consulted to conduct research for his manuscripts (comp. WÜSTEN 1970:191). Monuments became often a source and an inspiration for his literary writing. In his preliminary work for the Wanderungen durch die Mark Brandenburg, for example, he notes that he visited up to ten villages a day and frequently pushed himself to the limits of physical exhaustion: "Daß es keine Sehenswürdigkeiten mehr gibt, ist ein ganz besonderes Glück; ich bin so kathedralen- und gallerieenmüde, wie man nur sein kann, und jedes Schloß, das ich nicht $\mathrm{zu}$ sehen brauche, ist ein Segen für mich“ (FONTANE 1971: 107-108). His obsession, however, was not only directed towards monuments of German history, he was also as animated to explore, for example, French ones, even when his sightseeing tours were sometimes quite risky. Fontane tells nonchalantly the anecdote of his arrest during a sightseeing tour to the Jeanne D'Arc monument in Domrémy in France. While he banged against the statue with his cane to investigate its material, he was imprisoned by the French authorities since they suspected him to be involved in espionage (FonTANE 1973: 547). During the "monumental" Bismarck-era Fontane could indeed indulge into his passion since monuments boomed during in the second half of the nineteenth century in Germany. There was for example the sculpture cult around the medieval German emperor Frederick Barbarossa, Leo von Klenze's architectural feat of Walhalla (1842), which was a museum hall that exhibited German mythological figures, and the Herrmann monument in the Teutoburger forest (1872). The completion of the monumental gothic-style cathedral of Cologne in $1880^{2}$ represents yet another case. The preservation of monuments became a leading task for Prussian cultural politics and state officials were eager to administer committees building monuments and hiring conservators.

Pierre Nora's work on memory investigates a similar phenomenon in early nineteenth-century France; that is the trend to construct an abundance of so-called lieux de mémoire, locations of symbolic memory. Nora explains this hypertrophy of lieux de mémoire as symptoms of modernity; processes of democratization, massification, and the experience of temporal acceleration stir the desire to reconstruct a collective memory culture. According to Nora, modernity has superseded a community of "authentic" memory (milieux de mémoire), which were environments that reenact

\footnotetext{
${ }^{2}$ Whereas parts of the cathedral were built in the Middle Ages, the main structure was finished in the period between 1824 and 1880 .
} 
memory through rituals, traditions, and customs. These environments allowed an immediate relation between past and present and, thus, gave rise for creating a collective identity. Processes of modernity have abandoned this totemic memory culture; a loss that this is supposed to be compensated by producing realms of memory: "Lieux de mémoire exist because there are no longer any milieux de mémoire, settings in which memory is a real part of everyday experience" (NORA 1992: 1). Although the lieux de mémoire are products of loss and crisis, according to Nora's nostalgic theory, they still embody traces of the real memory. They still contain moments of mémoire, a mode of interacting with the past that is at odds with state ideology and rationalized historical discourses. Nora suggests: "Mémoire is rooted in the concrete: in space, gesture, image, and object. Histoire dwells exclusively on temporal continuities, on changes in things and in the relations among things" (NORA 1992: 3). By mémoire Nora suggests a form of historical imagination, a topical form of remembering, that differentiates from histoire as the intellectual and rational analysis of history. This form of mémoire, even though it attaches itself to the provisional lieu de mémoire emanates traces of the lost memory culture. As mentioned, recent research has often termed Fontane's representations of monuments as storage places for mémoire reinstalling traces of authentic memory within his history-obsessed era. Concentrating on Fontane's chapters about the Rheinsberg castle in the Wanderungen durch die Mark Brandenburg, a central location of Prussian history, my reading, however, goes against the grain of this romantic rechérche for mémoire by demonstrating that Fontane's representations of monuments experiment with heterogeneous perspectives on the past without centering them into one exclusive model of interpretation.

\section{The Rheinsbers Church: History as Arabesque}

The Wanderungen durch die Mark Brandenburg were published in four volumes during the years of 1862-1882. ${ }^{3}$ The books provide extensive depictions of the narrator's explorations of the region of the Mark-Brandenburg in Germany and they combine the genres of travel feuilleton, travel guide book, history book and personal diary. They are permeated by numerous anecdotes that the narrator tells about his impressions of the

\footnotetext{
${ }^{3}$ There is also a fifth volume Die Fünf Schlösser which does not carry the series title and was published in 1889 .
} 
landscape and culture, his encounters with the inhabitants of the region, and, of course, of the countless monuments in this area. The Wanderungen durch die Mark Brandenburg aim to convey regional knowledge about Fontane's homeland (he was born in Neuruppin in the Mark-Brandenburg) in a lifelike and pictorial fashion attractive to a popular readership. However, already in the foreword the narrator distances from any type of sensational sightseeing and spectacular tourist experiences. He states that a visit to the Mark Brandenburg is nothing for "gröbliche Augen, die gleich einen Gletscher oder Meersturm verlangen, um befriedigt zu sein" (FONTANE 1966: 12). A visit to this region craves special eyesight ["Wer das Auge dafür hat, der wag' es und reise (FONTANE 1966: 12)"]. ${ }^{4}$ No one should expect to see great spectacles rather minor details, unexpected insights, and marginal places determine the journey. A motto that could be true for the actual traveler as well as for the reader of Fontane's lengthy and extensive depictions his journeys.

Fontane devotes a whole chapter to Rheinsberg, which is placed in the first volume about the county Ruppin. The actual castle of Rheinsberg belonged to the crown prince Fredrick II (who inherited it from his father Wilhelm I) and he gave it to his younger art-loving brother Heinrich. The prince lived there for almost 50 years and conducted many changes to the building structure and its park. According to the narrator the area around Rheinsberg embodies "historische Erinnerung ersten Ranges" (FONTANE 1966: 262), which is in part due to the fact that it thrives with depictions monuments, such as the gravestone epitaph in the Rheinsberg church, the interior rooms of the royals, as well as the obelisk; all of them will be investigated in more detail in the following. The chapter on Rheinsberg begins with a depiction of its church, which according to the narrator embodies a historical merging place of the Prussian era of Frederick II and Prince Heinrich as well as the time of the Bredow family (the old noble family dynasty in the Havelland established since the $12^{\text {th }}$ century).

The church houses an epitaph, a grave memorial with inscriptions commemorating the Bredow family. Besides the textual part of the Bredow epitaph, Fontane's description incorporates also iconic and sculptural elements, such as live-size statues of Achim von Bredow and his wife Anna von Arnim, the family coat of arms, bas-reliefs with biblical scenes, as well as allegorical figurines. The narrator is captured

\footnotetext{
${ }^{4}$ For this reason there has been extensive research about the aspect of visuality in Fontane's Wanderungen durch die Mark Brandenburg. See for example Uwe HENTSCHEL (2003); Erdmut JosT (2003); Jerzy KAŁĄŻNY (2003).
} 
by its textual inscriptions that refer to the historical era, deeds, and beliefs of Achim of Bredow. After reading the verses he exclaims: "Welch' einfache und schöne Worte. Die ganze Kernigkeit jener Zeit tritt einem daraus entgegen" (FonTANE 1966: 267). The inscription aims to convey an authentic experience of the historical era, which is termed as an atmosphere of "whole-heartedness". The narrator put the Bredow-monument adjacent to the qualitatively inferior gravestones of the violinist Ludwig Christoph Pitschner, which Prince Heinrich devoted to him in memory of his favorite musician. He finds this statue with its French inscriptions an irritating and a dull contrast to the epitaph to the Bredow's. This juxtaposition of German "whole-heartedness" versus the artificiality of the French represents a common aspect in constructing national identity during this time. Fontane's Wanderungen durch die Mark Brandenburg often demarcates these boundaries against the French and incites the reader to identify on behalf of the Prussian-steered Germany.

However, the question remains if Fontane's text, and in particular his description of the Prussian monuments, can be reduced to this nationalist interpretation of the past. On the one hand, this reading makes sense, since for example the church epitaph seems to have the ability to communicate the historical national continuity from the German Holy Roman Empire until the Prussian era. The Bredow statutes are namely remnants of a death cult, in which the dead could interact and communicate with the public. The narrator tells the story that in 1844 the Bredow crypt was opened and the 40 coffins of the family members were put on open display and accessible to everyone. The people could come and visit the dead, bring them gifts, and remember their affiliations to them. At this point one could state that the narrator describes a moment of mémoire as historical remembering based on collective rituals. However, on the other hand, one has to ask if Fontane's text produce these effects of mémoire convincingly? Does the narrator understand the language of the dead? It is notable that according to the narrator the main sight, namely the Bredow crypt with the 40 coffins ("größte Sehenswürdigkeit" 269) remains invisible and untouchable for the visitors. This crypt remains locked up under the surface of the church floor, only a hollow space on the ground points to its existence: “[...] und nur noch am Schall des Tritts erkennt man auch heute noch, dass der Boden hohl ist, über den man hinwegschreitet" (FONTANE 1966: 269). Only a slight different resonance of the sound waves reminds of the burial site of the Bredow family. Its specific echo is only audible to the knowing visitor; it is 
easy to overhear and even if one knows this hollow area the dead remain locked up. The narrator cannot reach them; the thick ground remains an obstacle to pull the past in to the presence.

A ghost story underlines the inaccessibility of the past. During the period of the open display of the crypt, a ring was stolen from one of the corpses, namely from the beautiful young aristocrat Margarethe von Eichstädt. Her white grave dress looked still new when she was carried out of the crypt and she wore jewelry such as a small ring. When she had to move back into the crypt, her ring was gone. A normal grave theft is excluded, because the corpse's expensive necklace was still there and guards were on duty day and night. The narrator asks: "Wer trug ihn [den Ring] jetzt?" (FONTANE 1966: 270) and no answer is given. A remnant of the past is still haunting the present, but its tracing remains impossible. Margarethe's ghost spooks between the layers of time, but - as the echoes from the Bredow crypt - she does not mediate between these spheres. Her ghost embodies a type of blind spot, which disturbs the recuperation of mémoire and marks the empty spaces that occur in the attempts to reconstruct the past.

Once one gained suspicion about the communicative power of the monuments, one discovers other referential disturbances mediating the past into the presence. Let us take a look again at the ways how Fontane's text describes the Bredow epitaph in the Rheinsberg church:

\footnotetext{
Es ist ein Denkmal von ganz ungewöhnlichen Dimensionen, das bei wenigstens zehn Fuss Breite gewiss die doppelte Höhe hat. Es beginnt über der Holzeinfassung des Chorstuhls, reicht bis fast an die Decke hinauf, und besteht aus vier klar gegliederten Teilen. Oben das Bredowsche Wappen, zu beiden Seiten von allegorischen Figuren eingefasst; darunter zwei Basreliefs, von denen das eine, nach links hin, die Auswerfung Jonas aus dem Walfische, das andere nach rechts hin, die Auferstehung Christi darstellt; darunter in Lebensgröße der Figuren Achim von Bredows und seiner Gemahlin einer gebornen Anna von Arnim; und endlich viertens unter diesen beiden Bildnissen folgende Inschrift [...]. (FONTANE 267: 1966).
}

On top of the monument thrones the Bredow coat of arms, which gains through the sheer height of the monument an overpowering position. The Bredow family is placed like an absolutistic sovereign over the viewer's heads and entails a dominant position within the history of the region and its political developments. The coat of arms thus demarcates a dynastical view on the past; the origin of the aristocratic Bredow family goes back to the $12^{\text {th }}$ century and it has reigned the area until the $17^{\text {th }}$ century. This genealogical perspective is supported by the two life-size figures of Achim and Anna as 
Maurer, K. - Theodor Fontane's Representation of Monuments

the personified rulers of the dynastical course of history. Thus, history is perceived as steered by the hands of leading generations, whose power is maintained by genealogical relations and family connections. Considering what the narrator has told about the merging of the historical eras, one could state that so far Fontane's representation of the church actualizes this dynastical tradition in order to construct the continuity between the old dynasty and the Prussian era.

However, as the untraceable ghost of Margarethe, the Bredow epitaph also escapes these conclusions. Fontane's passages about this church monument do not frame the statues as well as their ornamental attributes (coat of arms, allegories, reliefs) into one all-encompassing image, rather is components remain separate. The coat of arms, for example, is flagged by two allegorical figurines, but they remain blank; the text does not mention their content or their shape. This omission could be read as a practical consideration of limiting the descriptive passage of the epitaph. However, this absence of further explanations also indicates symptoms for a crisis of allegorical representations of history. Since 1800 classical traditions of historical paintings began to question the interpretative power of historical allegories and their power to interpret the past faded. ${ }^{5}$ Fontane's text visualizes this decline of the allegorical not only by blanking it, but also the ways how the text represents two reliefs. The Bredow monument displays the two reliefs with biblical scenes that show the story of the Jonah and the resurrection of Christ. The story of Jonah is of particular interest since the spewing out of Jonah from whale can be read as a symbol for the death and resurrection of Christ; a reading that corresponds to the second relief of the Bredow epitaph. Thus, this interpretation opens up an eschatological perspective, which then could be reconnected to the dynastical perspective of the Bredow family whose reign expressed a religious order. The actual epitaph in the Rheinsberg church has a stark and surrounding frame construction, which in turn interlocks this eschatological perspective with the dynastic form of power.

But how does Fontane's passage negotiate these dynastic, allegorical and eschatological views on history? The paragraph about the epitaph does not mention any frames that would enable a synthesis of the diverging perspectives. Although a national perspective on the past is highlighted with the inscription, it remains unconnected to the

\footnotetext{
${ }^{5}$ I owe this reference to Uwe HeBEKUS (2003: 241). Hebekus mentions in this context the work by Günter Hess, who has has worked extensively on the change of allegorical traditions in representing history in nineteenth-century Germany.
} 
dynastical and eschatological elements. Together with the context of the hidden crypt and strange ghost stories, Fontane's monument lost a point of origin that would make sense out of the past. The epitaph suggests a reduplication of historical origins; a process which in turn suggests that the past has disintegrated into disjunctive puzzle pieces. Differently put: Fontane's passage about the epitaph utilizes the form of the arabesque. Whereas in Romantic poetic theory this ornamental form imposed an infinite abundance of poetic possibilities, the arabesque gains in Fontane's writing a historical dimension. Already in the foreword Fontane uses an arabesque image, which in turn could be used to signify a mode of understanding of history. The inquisitory narrator has to steer his rowing boat through thick organic formations before he can approach the castle of Rheinsberg (the heart of his historical journeys): "Nun glitt das Boot durch Teichrosen hin, deren lange Stengel wir (so klar war das Wasser) aus dem Grunde des Sees aufsteigen sahen; dann lenkten wir das Boot bis an den Schilfgürtel und unter die weit überhängenden Zweige des Parkes zurück" (FonTANE 1966: 10).

Like the interlacing stalks of the water lilies, the thick reed and the twigs that rank into the water, the approach to the past gains the quality of an ornamental image that does not suggest a linear thread, a beginning and an end. This arabesque process of interpreting the past is poeticized and the narrator weaves an intricate web of historical perspectives. Those do not center on a narrative about one historical origin; the reader has to jump from one fragment of meaning to the next creating a concomitant maze of observations. This mode of historical perception also determines the museum-like interior of the Rheinsberg castle.

\section{The Rheinsbers Castle: History as "Rumpelkammer"}

After the depiction of the Rheinsberg church the text focuses on the castle and its architectural style. The narrator emphasizes, however, that he can only give a broad impression of the castle's outer structure; ${ }^{6}$ the main attention is directed towards the interior rooms of Frederick II and Prince Heinrich. Thus one gains the impression that the narrator takes one onto a walk through a museum and one is given the chance to gain an insight into the private sphere of the royals. Frederick II had lived in the

\footnotetext{
6“Eine Beschreibung des Schlosses versuch’ ich nur in allgemeinsten Zügen” (FonTANE 1966: 272).
} 
Rheinsberg castle until his brother Prince Heinrich eventually made it into his home; the traces these royal figures left behind remind of their historical era, their different political roles, as well as their dissimilar personalities. The narrator is eager to recreate this national memory, and already the fact that there is a whole chapter on the Rheinsberg castle suggests that Fontane's text accentuates cultural and political highlights of the Prussian era. However, this national reconstruction of history is about to encounter some serious obstacles. Similar to the depiction of the epitaph a closer look onto the poetic composition of Fontane's text reveals disturbances in reconstructing the mémoire and histoire of this location of Prussian history. The problems of making sense of the past already begin with the church's old steward, who is supposed to guide the narrator through the castle and explain its history. Even though the visitors finally succeeded in waking him from his extensive afternoon nap, his effectiveness as a guide through the past is rather doubtful. According to his friend his stories about the portrait gallery of the royal family are completely arbitrary: "Sehen Sie, mein Herr, er hat eine Liste, auf der die Namen sämtlicher Portraits verzeichnet stehen, aber er nimmt es nicht so genau mit der Verteilung dieser Namen" (FonTANE 1966: 271). The randomness of the historical references uttered by the Brandenburgian 'cicerone' extents into the visit of Fredrick II's and Heinrich's private rooms of the castle. Delving into the royal interiors the narrator lists object after object, such as pictures, furniture, books, and small artifacts. The text registers these things via creating catalogic text passages and in particular the description of Heinrich's study room displays such an organization. There is Heinrich's table full of "Nippsachen" ["odds and ends" (FONTANE 1966: 277)]: a bird cage, a tobacco box, a precious coaster, and pot with paper flowers. Furthermore exhibited are Heinrich's drawings in Chinese ink, portraits of Prussian generals, and busts of Cicero, Voltaire, and Diderot. The narrator characterizes the museal exhibit with strikingly precise words: "Die Zimmer des Prinzen Heinrich, Prinz Heinrich selbst, alles ist bloß Zugabe, Material für die Rumpelkammer" (FONTANE 1966: 278). Indeed, the way how Fontane's text depict the historical site reminds one of visiting a dusty junk room, in which things accumulated over time and were never sorted out.

On the one hand, this assemblage of objects in this room works as a strategy to convey the impression of historical authenticity. The passages about Heinrich's room lists the objects in ways in which they seem merely to display superfluous data, yet this flow of information has the rhetorical effect to establish an impression of authenticity. 
Drawing on Barthes' essay “The Reality Effect”, we can understand Fontane's objects as representations of what the French theoretician calls insignificant detail. Comparable to the barometer in Gustave Flaubert's Madame Bovary, Barthes' example, the objects in Fontane's junk room carry no significance for the story. Yet their insignificance is precisely the condition of possibility for suggesting effects of authenticity. On the other hand, and that is similar to the depiction of the epitaph, these effects of authenticity remain singular entities, that are not integrated the form of a grand narrative about the Prussian era and its historical heroes. The narrator only describes the interior objects and its effects of historical authenticity, but these effects fails conveying a story around about the history of Rheinsberg and its royal inhabitants. The tabacco box remains next to the flowerpot coaster and one can only speculate about their meaning and function they once attained in the past ["Dieser Kasten muss bei bestimmter Gelegenheit als Untersatz für eine kostbare Blume gedient haben und von dem einen oder andern seiner Verehrer dem Prinzen überreicht worden sein." (FonTANE 1966: 277)]. The narrator is not only left wondering about the past, he also has to make the concession that the objects do not work as relying historical sources. Many of the exponents are in a condition, in which one almost cannot recognize them anymore. The worn out velvet plate of Heinrich writing desk lost its color and a ceiling fresco displaying the allegory (!) of "Die Ruhe beim Studieren" (FonTANe 1966: 275) in the Prince's study is run down: "Das Bild hat verhältnismässig gelitten [...]" (FonTANE 1966: 275). The narrator recapitulates his impressions with the following words: "Seitdem haben sich die Dinge sehr zum Schlimmen verändert." (FONTANE 1966: 275). The description of these objects, remnants, and rubble pieces do not obtain the status of relics that could ignite magic moments of memory; the power of mémoire disappears in the rubble of the "Rumpelkammer".

There are, however, attempts to rehabilitate Heinrich as a historical figure and there is a passage that tries to set the disparate elements of the junk room into a new light:

Historische Gestalten teilen nicht selten das Schicksal alter Statuen. Einzelne stehen durch eine Jahrtausend hin und immer leuchtend und immer bewundert auf dem Postament ihres Ruhmes; andere werden verschüttet oder in den Fluss geworfen. Aber endlich kommt der Moment ihrer Wiederauferstehung, und nun erst - neben den glücklicheren neuaufgerichtet - erwächst der Nachwelt die Möglichkeit des Vergleichs (FONTANE 1966: 279). 
The passage prognoses that after long periods of misunderstanding and misperception a potential rewriting of Prince Heinrich's legacy could be in order. However, the last word of the passage impedes this endeavor. Although the narrator speculates about Heinrich's deliverance, its realization remains quite doubtful, since the passage ends by stating that there only will be left the possibility of comparison. Comparing historical data represents one of the main practices in the fields of positivistic historicism ${ }^{7}$ that was en vogue in the academies during the last third of the nineteenth century in Germany; a practice that often resulted into historical relativism. When understanding of the past can merely achieve comparison, then historical interpretation is not only closely related to the analytical practices of natural science, but it is also no longer constructed within a philosophical-semantic framework. According to the historian Reinhart Koselleck, around the last third of the eighteenth century, history gained the power of becoming a "collective singular," it obtained a symbolic authority to create meaning and to make sense of the past. ${ }^{8}$ The passages about monuments from Fontane's Wanderungen durch die Mark Brandenburg take this foundational conceptualization of history as a point of friction is showing that essential categories of nation, freedom, or religion (all examples of collective singulars) no longer serve as unequivocal terms to interpret and make sense out of the past. The chance of being compared that might await Heinrich's figure in the future would only throw him into a new "junk room", where his memory would drown again in the abundance of data. This vision of a drowning or even suffocating within the abundance of historical data is also crucial for Fontane's representation about the obelisk.

\section{The Obelisk: Text and Stone}

Together with the Prince Heinrich's pyramid style gravestone, the narrator titles the obelisk as one of the main attractions in the Rheinsberg park. Already the foreword to the Wanderungen durch die Mark Brandenburg mentions the Egyptian-style monument and connects it with a specific mode of historical representation: "Von der anderen Seite des Sees her grüßte der Obelisk, der die Geschichte des Siebenjährigen Krieges im

\footnotetext{
${ }^{7}$ See comments on the relationship between historicism, positivism and relativism in the book by Moritz BAßLER, Christoph BREChT, Dirk NIEFANGER, Gotthart WUNBERG (1996: 19-22).

${ }^{8}$ See Reinhart KoSELLECK "Geschichte. Historie” (1972).
} 
Lapidarstil trägt" (FONTANE 1966: 10). The expression "Lapidarstil” is notable. From the Latin "lapis" ("stone") the word "lapidar" refers to Ancient Roman gravestone engravings. ${ }^{9}$ How can one interpret Fontane's interest in a "Lapidarstil" of history? On the one hand, it simply refers to the idea that the past, in this case the events of the Seven Years War (1756-1763), is represented through the medium "stone," namely as a sculpture with inscriptions on it. On the other hand, though, "lapidar" also refers to a type of surprising, but sharp and concise form of speech. "Lapidar" in this context stands for a non-ornamental and succinct form of typography that could fit the small surface of the monuments. In particular this meaning of "lapidar" is of interest when one tries to capture the significance of Fontane's obelisk. The narrator positions the obelisk as an affront against the official Prussian memory culture, as a "kritisches Kommentar, den der frondierende Prinz zu dem großen Geschichtsbuche seines Bruders geschrieben haben soll." (FonTANE 1966: 291). The text highlights that Prince Heinrich committed the obelisk to his brother August Wilhelm, who fell into disfavor with King Frederick II for political and personal reasons. Moreover, by erecting the obelisk one should be reminded of the 24 Prussian military generals that served in the Seven Years war. According to Fontane's text, Prince Heinrich was convinced that these men did not receive enough honoration by the king and that they were injustly forgotten in the public memory: "Der Obelisk richtete sich in seiner Kritik in erster Reihe gegen den König, aber an manchen Stellen und zwar gleichzeitig ausgesprochener Anerkennung unerachtet, doch auch gegen den einen oder andern der berühmtesten Generäle" (FONTANE 1966: 291). The obelisk, thus, should reinstall their presence in nineteenthcentury memorial culture and contribute their well-deserved respect and honor that they have been missed during Frederick II's era.

Fontane's text, however, goes against the grain of this official undertaking and performs a different mode of remembering for the reader than its narrator prescribes. The obelisk does not incite a whole new narrative about the legacy of August and the military men. The reason for this lies in Fontane's rather unconventional modes of representing the monument within the literary text. In his chapters about the obelisk all the Prussian generals are mentioned by name and the text duplicates the exact wording of the short characterization in the stone medallions; an undertaking that is divided into

\footnotetext{
${ }^{9}$ See "lapidar" in BROCKHAUs (1996: 87).
} 
the parts "Vorderfront", "Rechtsfront", "Linksfront" and "Rückfront." The following passage gives a taste of this style:

\begin{abstract}
Rückfront:
Von Goltz, Adjutant des Königs. Er wurde 1756 nach Preußen gesendet, um den Marschall Lehwald, welcher die Armee gegen die Russen befehligte, mit seinem Rat zu unterstützen. Ein umfassender, tiefblickender Geist, mit militärischen Kenntnissen vereint, würde seinen Namen verherrlicht haben, wenn sein alle Gefahren verachtender Mut in der Schlacht bei Jägersdorff ihn nicht dem Vaterland entrissen hätte.

Von Blumenthal, Major im Regiment Prinz Heinrich. Sein heller Geist, sein rechtliches Gemüt führten ihn Hand in Hand der Vollkommenheit entgegen [...].

Von Reder, Chef des Kavallerieregiments. [...] (FONTANE 1966: 289)
\end{abstract}

And these lists go on and on for more than 7 book pages mentioning all 28 generals. These copies of the inscriptions interrupt the flow of the narrative about the narrator's tour and its plot elements come to a complete halt. Similar to the interior rooms in the castle, the description of the obelisk gains also an excessive quality and the text again creates lists, catalogue, and name registers. Although there are short narrative snippets about the deeds of the generals, these paragraphs do not connect with each other. There is no story, no plot, no thread; only names, locations, and data remain as singular unconnected elements. The text acts like a type of copy machine precisely registering the shape and engravings of the obelisk performing a mimesis to the stone. Fontane's writing thus suggests as well the effect of petrifaction and the reader seems to be locked out from any interaction or understanding of the text. Reading this petrifaction process from a culture historical perspective one could conclude that Fontane's obeliskscriptures epitomize the emptiness of memory culture of his era. Obelisks were definite constituencies of the monument boom of nineteenth-century Germany and they often were erected as markers of national history. ${ }^{10}$ The obelisk in the Wanderungen durch die Mark Brandenburg reflects this interest in Egyptian style monuments in more intricate ways: it neither affirms the official memory culture nor does it undermine it, but it rather suggests suffocating memory by petrifying it. Thus, Fontane's "Lapidarstil" gains a new dimension, by which the medium of the stone no longer forces the succinct style of utterance, but rather suggests that the object of investigation escapes textual representation. The obelisk shaped column not only echoes a trend in German memory

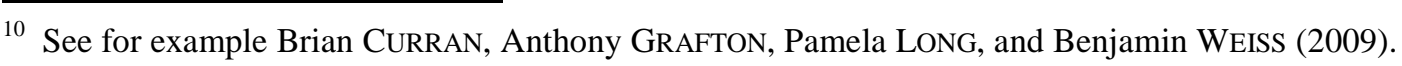


culture during the nineteenth century, it also refers to a different medial form to communicate: hieroglyphs, iconic language and images.

Not only the obelisk, but also all the other discussed monuments in the Wanderungen durch die Mark Brandenburg embody seismographs registering the multimediality of historical memory culture in Germany during the last third of the nineteenth century. This memory culture was primarily visual and it was constituted by the monuments, museums, and visual spectacles (such as world exhibitions, historical panorama, and historical festivals). ${ }^{11}$ All these media processed and constructed representations of the past under different premises. Fontane's monuments precisely register this multi-medial memory boom and reflect by means of paradoxical modes of representation the heterogeneity of the German visual memory culture during this time. ${ }^{12}$ My readings of Fontane's representations of monuments have demonstrated that they convey multi-perspective views on the past. They do not shape, for example, an exclusive "nationalist" approach, in which the monuments would support the official political agendas of Prussia's memorial culture, nor do they fixate another history philosophical model to interpret the past. The passages about the epitaph, the interior of the Rheinsberg castle as well as the obelisk de-center the concept of a "collective singular". In fact histoire and mémoire no longer center the representation of the past, but rather Fontane's monuments open up paradoxical and rivalizing views. Eschatological, allegorical, dynastic, allegorical, and arabesque perspectives are cited and arranged into shifting constellations. The Wanderungen durch die Mark Brandenburg, thus, pay tribute to their title; they describe indeed "wanderings" through the past without arche or telos.

\section{Bibliography}

BARTHES, Roland. "The Reality Effect." The Rustle of Language. Trans. Richard Howard, Oxford, UK: Basil, Blackwell, 1981. p. 141-148.

BAßLER, Moritz and Christoph Brecht, Dirk Niefanger, Gotthart Wunberg's Historismus und literarische Moderne: Tübingen. Max Niemeyer, 1996. p. 19-22.

BRocKHAus: Die Encyklopädie in 24 Bänden. Bd.13. Leipzig: Brockhaus, 1996. p. 87.

\footnotetext{
${ }^{11}$ An aspect that is often underexposed in research about nineteenth-century historical discourses. Of course, however, there was also a memory culture within the written discourses: The boom of historical novels, for example, made historical figures into protagonists of bestsellers that were mass-produced and devoured by the public. By the 1860s the public demand for realist-historical prose was at an unprecedented high: the trend started in the 1850s and continued to the 1890s. See Hartmut EGGERT (1971) and Harro MÜLLER (1997).

${ }^{12}$ See for example Andrew CUSACK (2009).
} 
Maurer, K. - Theodor Fontane's Representation of Monuments

Curran, Brian; Grafton, Anthony; Long, Pamela; Weiss, Benjamin. Obelisk: A History. Cambridge, MA: MIT Press, 2009.

CUSACK, Andrew. „Civibus aevi futuri: Panoramic Historiography in Fontane's Wanderungen durch die Mark Brandenburg," In: The Modern Language Review 104.3 (2009): 746761.

EGGERT, Hartmut. Studien zur Wirkungsgeschichte des deutschen historischen Romans 18501875. Frankfurt a. M.: Vittorio Klostermann, 1971.

FontANE, Theodor. Wanderungen durch die Mark Brandenburg. Vol.1. Ed. Walter Keitel. Frankfurt a. M.: Ullstein, 1966.

“(614) Warnemünde 15. Sep. 71,“ Briefe III: Briefe an Mathilde von Rohr, ed. Kurt Schreinert, Berlin: Propylän Verlag, 1971.p. 107-108.

. „Kriegsgefangen.“ Sämtliche Werke: Aufsätze, Kritiken, Erinnerungen. Bd. 4. ed. Walter Keitel. Darmstadt: Wissenschaftliche Buchgesellschaft, 1973. p. 541-689.

Brief an Theodor Storm vom 14.2. 1854 Fontanes Briefe in 2 Bänden, B1, 146

GRAEVENITZ, Gerhart v. „Memoria und Realismus: Erzählende Literatur in der deutschen ,Bildungspresse“" “In: Memoria: Vergessen und Erinnern. Eds. Anselm Haverkamp und Renate Lachmann, München: Fink: 1993. p. 283-304.

HebeKus, Uwe. Klios Medien. Die Geschichtskultur des 19. Jahrhunderts in der historistischen Historie und bei Theodor Fontane. Tübingen: Niemeyer, 2003.

HENTSCHEL, Uwe. „Märkische Bilder oder ,Wanderungen?: Anmerkungen zur Textsortenproblematik." In: Geschichte und Geschichten aus Mark Brandenburg (2003). p. 81-94.

HESS, Günter. "Allegorie und Historismus. Zum Bildgedächtnis des späten 19. Jahrhunderts." In: Verbum und Signum.Beiträge zur mediävistischen Bedeutungsforschung. Festschrift für Friedrich Ohly. Eds. Hans Fromm, Wolfgang Harms and Uwe Ruberg. Vol. 1. München: Fink, 1975. p. 555-591.

JosT, Erdmut. "Das poetische Auge: Visuelle Programmatik in Theodor Fontanes Landschaftsbildern aus Schottland und der Mark Brandenburg." In: Geschichte und Geschichten aus Mark Brandenburg (2003). p. 63-80.

KALAZNY, Jerzy. „, Das landschaftliche Auge : Zum Sehen und Wandern in Wilhelm Heinrich Riehls Wanderbuch im Vergleich mit Fontanes Wanderungen durch die Mark Brandenburg." In: Geschichte und Geschichten aus Mark Brandenburg (2003). p. 159174.

KOSELLECK, Reinhart. „Geschichte, Historie,“ In: Geschichtliche Grundbegriffe: Historisches Lexikon zur politisch-sozialen Sprache in Deutschland. Bd. 2. Eds. Otto Brunner, Werner Conze, Reinhart Koselleck, Stuttgart: Klett, 1975. p. 593-717.

MÜLLER, Harro. "Thesen zur Geschichte des Historischen Dramas und des historischen Romans (1773-1888).” In: Geschichtsdiskurs. Vol. 3. Frankfurt a. M.: Fischer, 1997. p. 100121.

NORA, Pierre. Rethinking the French Past: Realms of Memory. Vol. 1. Ed. Laurence D. Kritzman. Transl. Arthur Goldammer. New York: Columbia University Press, 1992.

THIELKING, Siegrid. „Denkmal, Turm, Grab und Gruft. Orte der „Memoria“ und des „KulturBildlichen" bei Theodor Fontane." In: Theodor Fontane: Am Ende des Jahrhunderts. Vol. 3. Eds. Hanna Delf von Wolzogen and Helmuth Nürnberger. Würzburg: Könighausen und Neumann, 2000. p. 15-27

TONTSCH, Ulrike. „Das Dichterdenkmal als Vehikel nationaler Wertevermittlung. Zur Rezeption Fontanes zwischen 1900 und 1914.“ In: Formen realistischer Erzählkunst. Festschrift für Charlotte Jolles. Ed. Jörg Thunecke. Nottingham: Sherwood Press Agencies, 1979. p. 381-394.

WÜSTEN, Sonja. „Die historischen Denkmale im Schaffen Theodor Fontanes.“ In: Fontane Blätter 2: Kreis der Freunde Theodor Fontanes (1970) 3: 187-194. 